\title{
EFEKTYWNOŚĆ WZMOCNIENIA BELEK ŻELBETOWYCH WSTĘPNIE NAPRĘŻONYMI TAŚMAMI CFRP
}

\begin{abstract}
Taśmy kompozytowe są obecnie szeroko wykorzystywane w budownictwie. Dzięki bardzo dobrym parametrom mechanicznym doskonale nadają się do wzmacniania konstrukcji żelbetowych. Wzmacnianie może odbywać się w sposób bierny, gdzie taśmy są wyłącznie przyklejane do powierzchni betonu lub czynny, w którym taśmy są przyklejane w stanie naprężonym i najczęściej dodatkowo kotwione do konstrukcji. W artykule przedstawiono badania belek żelbetowych wzmocnionych na zginanie za pomocą taśm wstępnie naprężanych oraz dodatkowo taśm przyklejanych biernie. Głównym celem badań była analiza efektywności wzmocnienia belek, wpływu poziomu naprężenia taśm CFRP oraz zastosowania zakotwień mechanicznych. Dodatkowym celem badań była doświadczalna weryfikacja działania nowego systemu NPS II do wzmacniania konstrukcji wstępnie naprężonymi taśmami CFRP. Belki, po wzmocnieniu taśmami, zostały poddane obciążeniu statycznemu w schemacie czteropunktowego zginania. Wzmocnione belki charakteryzowały się wyższą nośnością graniczną w porównaniu $\mathrm{z}$ belką referencyjną (20 $\div 30 \%$ w przypadku belek wzmocnionych biernie i ok. $55 \%$ w przypadku belek sprężonych). Wzrost poziomu naprężenia taśm skutkował wzrostem sztywności belek, nie miał natomiast wpływu na poziom wzrostu ich nośności. Ponadto, wraz ze wzrostem poziomu naprężenia taśm zanotowano spadek plastyczności belek. Zastosowanie zakotwień mechanicznych pozwoliło na przedłużenie pracy belek o dodatkową poawaryjną fazę, od momentu odspojenia taśm, do zniszczenia zakotwień. Badania potwierdziły także przydatność nowego systemu NPS II do wzmacniania konstrukcji żelbetowych naprężonymi taśmami CFRP.
\end{abstract}

Słowa kluczowe: sprężanie, system wzmacniania, włókno węglowe, zakotwienia, zginanie

\section{Wprowadzenie}

Technologia wzmacniania konstrukcji żelbetowych na zginanie przy użyciu taśm kompozytowych CFRP (ang. carbon fibre reinforced polymer) jest obecnie szeroko stosowana w praktyce [1]. Dzięki swoim licznym zaletom, takim jak bardzo wysoka wytrzymałość taśm, odporność na korozję i zmęczenie, łatwość

\footnotetext{
${ }^{1}$ Bartosz Piątek, Politechnika Rzeszowska, Zakład Dróg i Mostów, ul. Poznańska 2, 35-084 Rzeszów; tel. 178651022; piatek@prz.edu.pl
} 
aplikacji czy możliwość znacznego podniesienia nośności elementu przy pomijalnym wzroście ciężaru i niewielkiej ingerencji w estetykę, technologia ta coraz częściej wypiera konwencjonalne metody wzmacniania elementów żelbetowych.

Najpopularniejszym i najprostszym sposobem wzmacniania konstrukcji żelbetowych taśmami CFRP jest ich bierne przyklejanie do powierzchni betonu. Badania dowodzą jednak, że nie jest to metoda efektywna z punktu widzenia stopnia wykorzystania drogiego materiału kompozytowego. Jedynie $30 \div 35 \%$ wytrzymałości taśm na rozciąganie może być wówczas wykorzystane w stanie granicznym nośności [2, 3, 4].

Efektywność wzmacniania konstrukcji przy użyciu taśm CFRP może być znacząco zwiększona poprzez skuteczne kotwienie i/lub wstępne naprężenie taśm przed przyklejeniem do wzmacnianego elementu [4, 5]. Sprężanie belek taśmami skutkuje także redukcją ugięcia i zarysowania [5]. Dzięki temu możliwa staje się poprawa parametrów belki nie tylko w zakresie jej stanów granicznych nośności, ale także w zakresie użytkowalności i trwałości.

Obecnie na całym świecie, w tym także i w Polsce, zostały opracowane liczne systemy wzmacniania konstrukcji za pomocą tej technologii [6]. W ciągu ostatnich dwóch lat, dzięki współpracy spółki Tines Composites, Politechniki Rzeszowskiej oraz Akademii Górniczo-Hutniczej, została opracowana druga generacja polskiego systemu wzmacniania konstrukcji budowlanych Neoxe Prestressing System (NPS) [7]. Przeprowadzone prace naukowo-badawcze pozwoliły na zwiększenie nośności zakotwień wykorzystywanych w systemie oraz zaprojektowanie i wykonanie nowego urządzenia naciągowego, umożliwiającego naciąg taśm ze znacznie większą siłą.

W artykule zaprezentowano badania belek żelbetowych wzmocnionych na zginanie przy użyciu taśm CFRP wstępnie naprężanych i kotwionych do konstrukcji oraz przyklejanych biernie. W belkach sprężonych zastosowano różny poziom wstępnego naprężenia taśm. Belki zostały obciążone statycznie w schemacie czteropunktowego zginania. Głównym celem opisanych badań była analiza efektywności wzmocnienia belek wraz z oceną wpływu zastosowania zakotwień mechanicznych $\mathrm{w}$ belce wzmocnionej taśmą przyklejoną biernie oraz wpływu poziomu naprężenia taśm CFRP. Dodatkowo podczas badań przeprowadzono doświadczalną weryfikację działania nowego systemu wzmacniania NPS II.

\section{Program badań}

\subsection{Opis belek}

Przedmiotem badań były belki żelbetowe zbliżone pod względem wymiarów geometrycznych i zastosowanego zbrojenia do prefabrykowanych belek mostowych. Pozwoliło to na uwzględnienie efektu skali, który jest niezwykle istotny $\mathrm{w}$ tego typu badaniach. Belki miały prostokątny przekrój poprzeczny 
o wymiarach 0,50×0,42 $\mathrm{m}$ i długość $6,0 \mathrm{~m}$. Zostały one wykonane $\mathrm{z}$ betonu klasy C45/55. Do zbrojenia belek zastosowano stal klasy B500SP. Zbrojenie podłużne, dolne i górne, stanowiły trzy pręty $\phi 25 \mathrm{~mm}$, a strzemiona pręty $\phi 12 \mathrm{~mm}$ (rys. 1). Środkowy pręt zbrojenia dolnego został odgięty w strefach przypodporowych, aby zapewnić możliwość bezkolizyjnego montażu zakotwień taśm oraz urządzenia naciągowego. Wysoki stopień zbrojenia górnego został zastosowany w celu wykluczenia mechanizmu zniszczenia belek zapoczątkowanego zmiażdżeniem betonu w strefie ściskanej. Wystąpienie takiego mechanizmu mogłoby uniemożliwić obserwację zniszczenia wzmocnienia taśmami CFRP w strefie rozciąganej belek, co było jednym z celów badań.

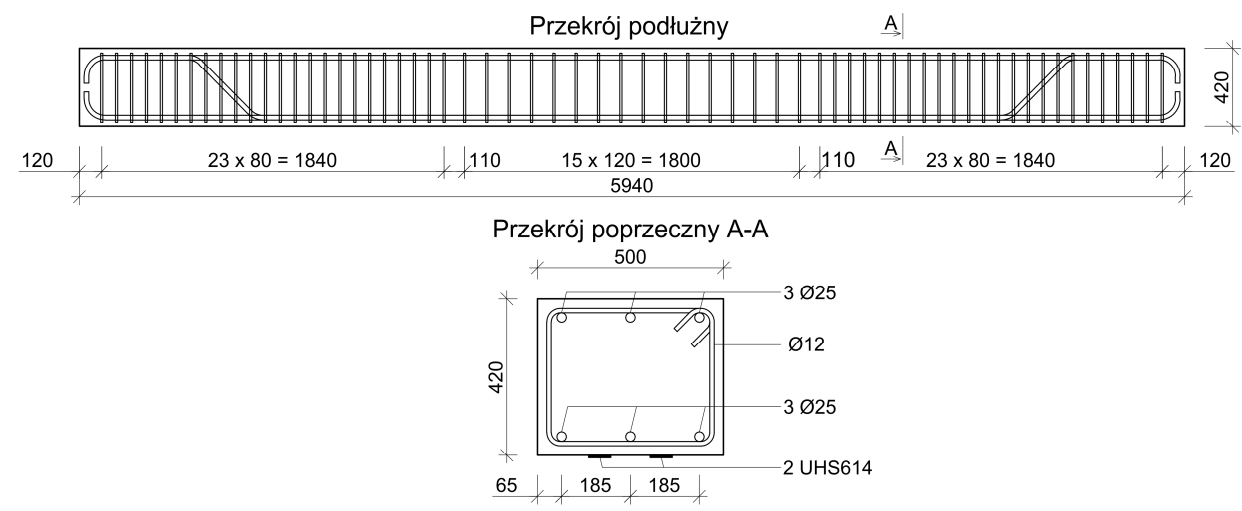

Rys. 1. Zbrojenie stalowe belek żelbetowych

Fig. 1. Steel reinforcement of RC beams

\subsection{Opis wzmocnienia}

Badania przeprowadzono na sześciu identycznych belkach żelbetowych. Pierwszą belkę (B1) pozostawiono bez wzmocnienia jako referencyjną. Druga belka (B2) została wzmocniona taśmami CFRP przyklejonymi biernie do rozciąganej powierzchni betonu. Kolejne cztery belki (B3-B6) zostały wzmocnione przez sprężenie taśmami ze zróżnicowanym poziomem naprężenia w wysokości kolejno $0 \%, 30 \%, 40 \%, 50 \%$ wytrzymałości kompozytu na rozciąganie $\left(\mathrm{f}_{\mathrm{fu}}\right)$. W przypadku tych belek taśmy kompozytowe były kotwione na końcach do powierzchni betonu przy użyciu systemowych zakotwień mechanicznych. Parametry wzmocnienia badanych belek podano w tabl. 1 .

Do wzmocnienia każdej belki użyto dwóch taśm kompozytowych NEOXEPLATE UHS 614, o przekroju poprzecznym $60 \times 1,4 \mathrm{~mm}$, wytrzymałości na rozciąganie ( $\left.\mathrm{f}_{\mathrm{fu}}\right) 3200 \mathrm{MPa}$, module sprężystości $\left(\mathrm{E}_{\mathrm{f}}\right) 160 \mathrm{GPa}$ i odkształceniu granicznym $\left(\varepsilon_{\mathrm{fu}}\right) \sim 2,0 \%$. Charakterystyki materiałowe taśm CFRP deklarowane przez producenta [8] zweryfikowano na podstawie serii badań dziewięciu próbek. Współczynnik zmienności wyznaczanych parametrów nie przekraczał $6 \%$. 
Tabela 1. Parametry wzmocnienia belek

Table 1. Strengthening parameters of beams

\begin{tabular}{|c|c|c|c|c|c|}
\hline Belka & $\begin{array}{l}\text { Poziom naprę- } \\
\text { żenia taśm }\end{array}$ & $\begin{array}{c}\text { Siła naciągu } \\
\text { taśmy }\end{array}$ & $\begin{array}{l}\text { Wstępne od- } \\
\text { kształcenia } \\
\text { taśmy }\end{array}$ & $\begin{array}{l}\text { Wstępne naprę- } \\
\text { żenia w taśmie }\end{array}$ & $\begin{array}{l}\text { Obecność } \\
\text { zakotwień }\end{array}$ \\
\hline & {$[-]$} & {$[\mathrm{kN}]$} & {$[\% o]$} & {$[\mathrm{MPa}]$} & {$[-]$} \\
\hline B1 & \multicolumn{5}{|c|}{ belka referencyjna bez wzmocnienia } \\
\hline B2 & $0 \% \mathrm{f}_{\mathrm{fu}}$ & - & - & - & Nie \\
\hline B3 & $0 \% \mathrm{f}_{\mathrm{fu}}$ & - & - & - & Tak \\
\hline B4 & $30 \% \mathrm{f}_{\mathrm{fu}}$ & 81 & 6,0 & 960 & Tak \\
\hline B5 & $40 \% \mathrm{f}_{\mathrm{fu}}$ & 108 & 8,0 & 1280 & Tak \\
\hline B6 & $50 \% \mathrm{f}_{\mathrm{fu}}$ & 134 & 10,0 & 1600 & Tak \\
\hline
\end{tabular}

Kotwienie taśm w belkach realizowano za pomocą dwóch rodzajów zakotwień mechanicznych. Schemat budowy zakotwień przedstawiono na rys. 2. Zakotwienia są zbudowane z trzech blach stalowych, dwóch zewnętrznych i jednej wewnętrznej, dystansowej, które są połączone obwodowo poprzez spawanie. W obszarze wewnętrznym zakotwienia, pomiędzy blachami zewnętrznymi zamocowana jest taśma kompozytowa, a w obszarze zewnętrznym zlokalizowane są otwory do mocowania zakotwienia do podłoża oraz otwory gwintowane do mocowania urządzenia naciągowego (tylko w zakotwieniu czynnym).

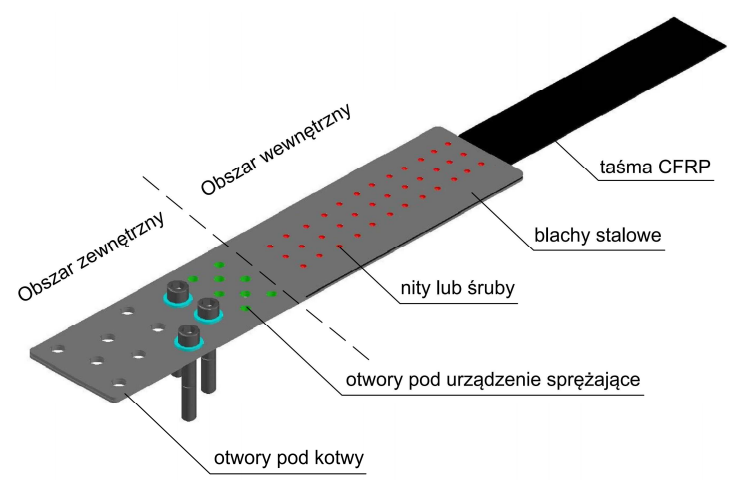

Rys. 2. Schemat budowy zakotwienia taśmy

Fig. 2. Schematic overview of the plate anchorage

Zakotwienia różniły się sposobem mocowania taśmy pomiędzy blachami stalowymi. Do kotwienia taśm w belce B3 użyto zakotwień wykorzystujących połączenie klejowo-nitowe. Zakotwienia te zostały przebadane w warunkach obciążeń doraźnych i zmęczeniowych, a wyniki tych badań przedstawiono w pracach $[9,10]$. Taśmy $\mathrm{w}$ belkach sprężonych (B4-B6) zostały naprężone 
przy użyciu nowego rodzaju zakotwień, w których zastosowano śrubowe połączenie cierne. Nity zastąpiono śrubami sprężającymi, a klej cienką warstwą żywicy epoksydowej.

Sprężenie belek zrealizowano za pomocą nowego systemu wzmacniania konstrukcji budowlanych Neoxe Prestressing System II (NPS II). System składa się z urządzenia naciągowego oraz odcinka taśmy kompozytowej wyposażonego w prefabrykowane zakotwienia, dostosowane do urządzenia. Urządzenie naciągowe składa się z trzech montowanych osobno elementów: szyn prowadzących, wózka mocowanego do zakotwienia czynnego oraz bloku oporowego z siłownikiem hydraulicznym, umożliwiającym uzyskanie maksymalnej siły sprężającej na poziomie $170 \mathrm{kN}$ (rys. 3). Dzięki optymalizacji wszystkich elementów pod względem ciężaru, urządzenie jest lekkie i umożliwia szybką i łatwą instalację taśm na wzmacnianej konstrukcji. W skład systemu wzmacniania wchodzi również klej Neopoxe 30 o wytrzymałości na rozciąganie powyżej $30 \mathrm{MPa}$, module sprężystości ok. $10 \mathrm{GPa}$ i przyczepności do betonu ok. $5 \mathrm{MPa}$ (parametry deklarowane przez producenta [11]), służący do mocowania odcinka taśmy pomiędzy zakotwieniami do powierzchni betonu.

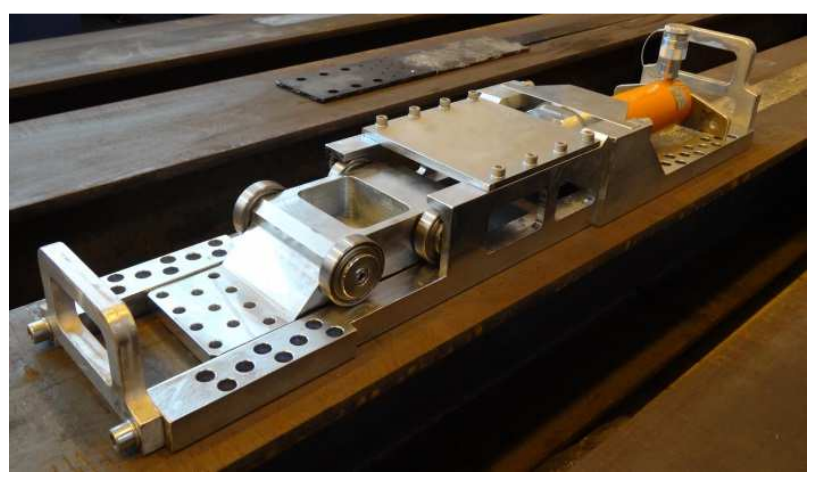

Rys. 3. Urządzenie naciągowe

Fig. 3. Tensioning device

Wszystkie belki zostały wzmocnione na stanowisku montażowym w pozycji sufitowej (od spodu), w celu uwzględnienia wpływu ciężaru własnego belek. Powierzchnia betonu belek przed przyklejeniem taśm została wyszlifowana, odpylona i odtłuszczona. W przypadku belki wzmocnionej biernie bez zakotwień (B2) na wcześniej odtłuszczone i aktywowane taśmy kompozytowe nałożono warstwę kleju i przyklejono taśmy do powierzchni belek. W belce B3 przed przyklejeniem taśm wytrasowano i wywiercono otwory pod kotwy zakotwień, a następnie przyklejono taśmy i zamontowano zakotwienia przy użyciu kotew mechanicznych $\phi 16 \mathrm{~mm}$. W przypadku belek sprężonych (B4-B6), po przygotowaniu powierzchni betonu i taśm kompozytowych, taśmy były mocowane do podłoża po stronie zakotwienia biernego. Następnie, po stronie czynnej, kotwio- 
no do belek urządzenie naciągowe, nakładano klej i naprężano taśmy do odpowiedniej wartości siły sprężającej za pomocą siłownika hydraulicznego. Po naprężeniu taśm były montowane kotwy w zakotwieniu czynnym, siłownik hydrauliczny był zwalniany, urządzenie naciągowe demontowane, a taśmy dociskano do powierzchni belek i usuwano nadmiar kleju.

Sprężenie skutkuje wprowadzeniem dodatkowych sił wewnętrznych w belce, a co za tym idzie zmianą rozkładu odkształceń w przekrojach. Na rys. 4 przedstawiono przykładowe wykresy charakteryzujące zmiany stanu odkształceń w przekroju środkowym belki B6 (tj. o największym poziomie naprężenia taśm) w kolejnych etapach wzmacniania: przed sprężeniem taśmami (odkształcenia wywołane obciążeniem ciężarem własnym - rys. 4a), odkształcenia wywołane siłą sprężającą (rys. 4a) oraz sumaryczne odkształcenia po wzmocnieniu (rys. 4c).

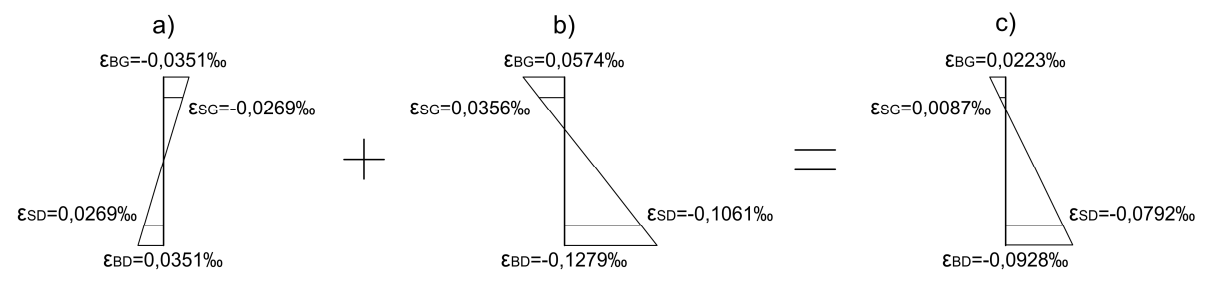

Rys. 4. Stan odkształceń w przekroju środkowym belki B6: a) przed wzmocnieniem, b) od sprężenia, c) po wzmocnieniu

Fig. 4. Strain state in the middle section of the beam B6: a) before strengthening, b) prestressing only, c) after strengthening

\subsection{Metodyka badawcza}

Badania przeprowadzono w hali Wydziałowego Laboratorium Badań Konstrukcji Politechniki Rzeszowskiej, na specjalnie przygotowanym stanowisku badawczym (rys. 5). Rozpiętość belek w osiach podparcia wynosiła 5,6 m. Obciążenie było realizowane za pomocą siłownika hydraulicznego na maszynie Instron Schenck o maksymalnej sile $630 \mathrm{kN}$. Schemat czteropunktowego zginania uzyskano poprzez rozłożenie obciążenia z siłownika hydraulicznego za pomocą stalowej belki trawersowej. Obciążanie belek realizowano w kilku cyklach. Po wykonaniu obciążenia próbnego, przykładano siły wywołujące w belkach momenty zginające o wartości od 100 do $300 \mathrm{kNm}$. W ostatnim cyklu belki obciążano do zniszczenia. 


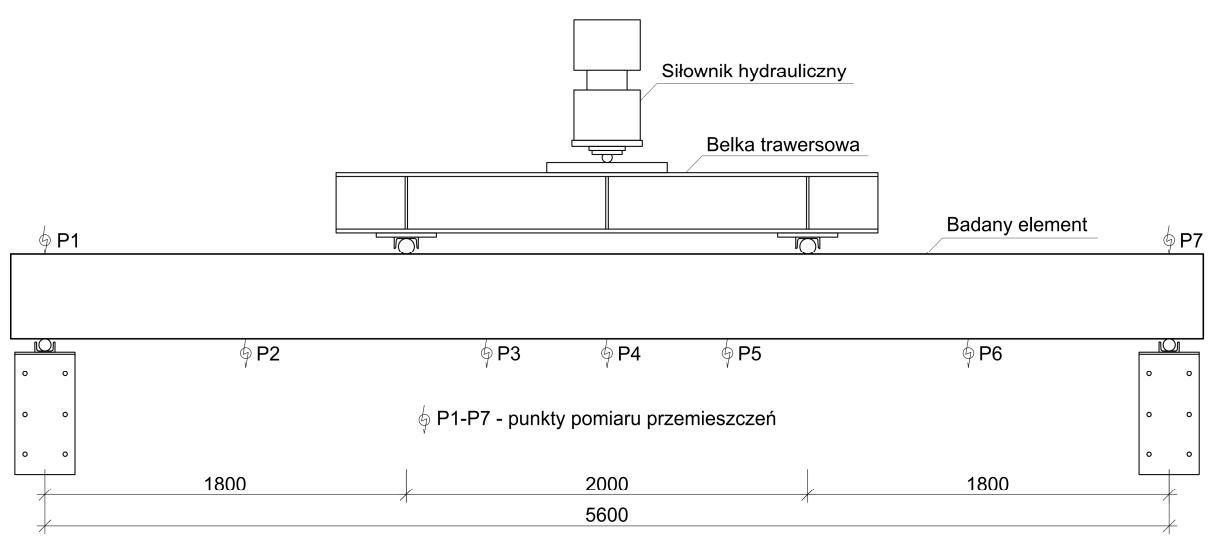

Rys. 5. Schemat badania belek

Fig. 5. Test setup

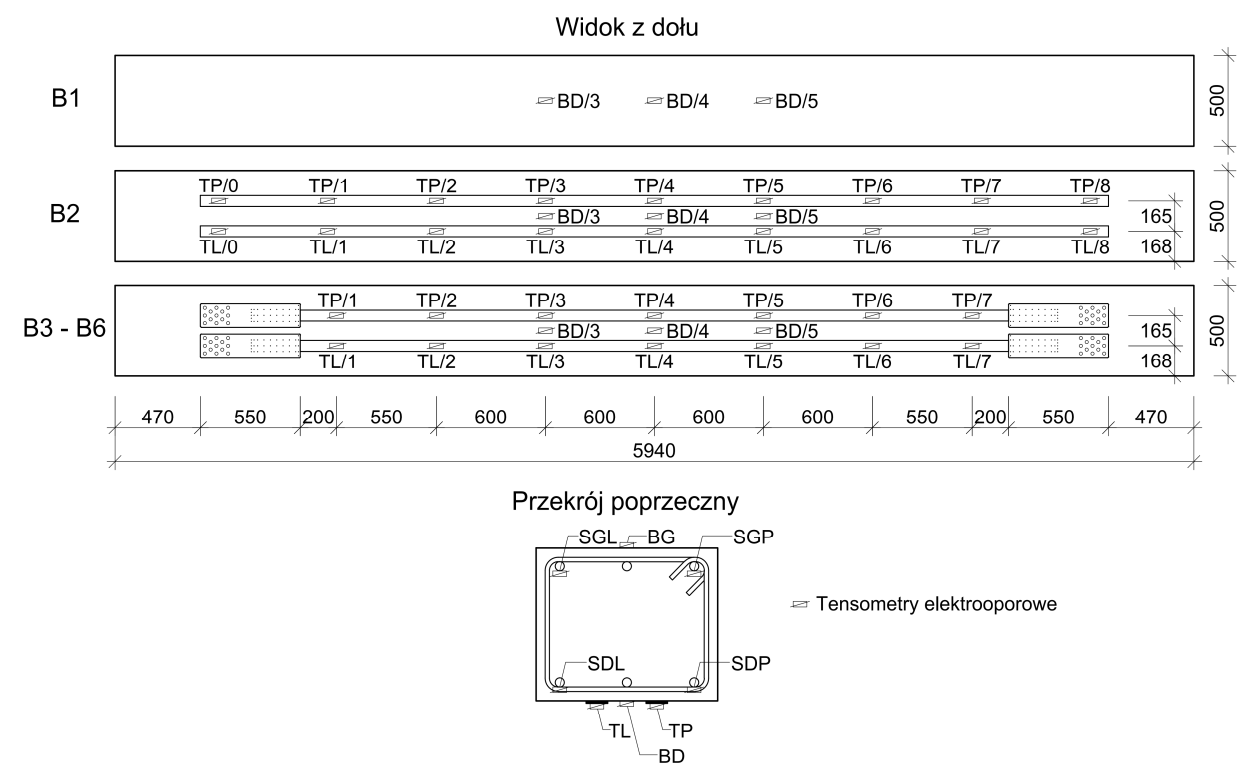

Rys. 6. Rozmieszczenie punktów pomiarowych odkształceń (B - beton, $\mathrm{S}-$ stal, T - taśma CFRP)

Fig. 6. Location of strain measurement points (B - concrete, $\mathrm{S}$ - steel, T - CFRP strip)

Podczas badań prowadzono ciągły pomiar siły, pomiar ugięć belek oraz kontrolowano osiadanie podpór (rys. 5). W strefie stałego momentu zginającego mierzono odkształcenia górnych i dolnych płaszczyzn betonu, stali prętów zbrojeniowych oraz odkształcenia taśm kompozytowych na całej ich długości (rys. 6). Do pomiaru przemieszczeń użyto czujników indukcyjnych typu WA-20 i WA-100, odkształcenia w betonie mierzono tensometrami typu RL-50/500, 
a odkształcenia stali i kompozytu tensometrami typu TFs-10/120. W kolejnych cyklach przykładanego obciążenia prowadzano inwentaryzację rys na bocznych powierzchniach belek. Po uzyskaniu nośności granicznej zinwentaryzowano szczegółowo postać zniszczenia belki i elementów wzmocnienia.

\section{Wyniki badań}

Zestawienie najważniejszych wyników badań belek zamieszczono w tabl. 2. Dla każdej belki podano wartość momentu rysującego, momentu uplastycznienia stali zbrojeniowej oraz nośności granicznej. Za nośność graniczną belek przyjęto maksymalną wartość momentu zginającego uzyskaną podczas badań. Dodatkowo podano maksymalne odkształcenia taśm kompozytowych w chwili zniszczenia (wraz z odkształceniami wstępnymi) oraz opis postaci zniszczenia.

Tabela 2. Wyniki badań

Table 2. Test results

\begin{tabular}{|c|c|c|c|c|c|}
\hline \multirow{3}{*}{ Belka } & $\begin{array}{l}\text { Moment } \\
\text { rysujący }\end{array}$ & $\begin{array}{c}\text { Moment } \\
\text { uplastycz- } \\
\text { nienia stali }\end{array}$ & $\begin{array}{l}\text { Nośność } \\
\text { graniczna }\end{array}$ & $\begin{array}{c}\text { Maksymalne } \\
\text { odkształcenie } \\
\text { taśm }\end{array}$ & Postać zniszczenia \\
\hline & $\mathrm{M}_{\mathrm{cr}}$ & $\mathrm{M}_{\mathrm{y}}$ & $\mathrm{M}_{\mathrm{u}}$ & $\varepsilon_{\max }$ & - \\
\hline & {$[\mathrm{kNm}]$} & {$[\mathrm{kNm}]$} & {$[\mathrm{kNm}]$} & {$[\% \circ]$} & {$[-]$} \\
\hline B1 & 55 & 266 & 272 & - & uplastycznienie zbrojenia \\
\hline $\mathrm{B} 2$ & 70 & 318 & 332 & 5,9 & odspojenie taśm \\
\hline B3 & 72 & 321 & 361 & 7,8 & $\begin{array}{c}\text { odspojenie taśm, } \\
\text { wysunięcie z zakotwień }\end{array}$ \\
\hline B4 & 111 & 371 & 424 & 15,8 & $\begin{array}{l}\text { odspojenie i zniszczenie } \\
\text { taśm }\end{array}$ \\
\hline B5 & 120 & 394 & 415 & 16,4 & $\begin{array}{l}\text { odspojenie, wysunięcie } \\
\text { i zniszczenie taśmy }\end{array}$ \\
\hline B6 & 136 & 419 & 428 & 16,7 & $\begin{array}{c}\text { odspojenie taśm, } \\
\text { wysunięcie z zakotwień }\end{array}$ \\
\hline
\end{tabular}

Momenty rysujące w belkach B2 i B3 były zbliżone i większe o ok. 30\% w porównaniu z belką referencyjną. W przypadku belek sprężonych wzrost ten był jeszcze większy i wynosił od $100 \%$ dla belki B4 do prawie $150 \%$ dla belki B6. Podobną zależność zanotowano w przypadku momentu, przy którym dochodzi do uplastycznienia zbrojenia stalowego. W belkach B2 i B3 wzrost tej wartości wynosił ok. 20\%, a w belkach B4-B6 od 40 do niemal $60 \%$ w porównaniu do belki referencyjnej. Wartość momentu rysującego i momentu uplastycznienia zbrojenia stalowego w belkach sprężonych wzrastała wraz ze wzrostem poziomu naprężenia taśm. Inaczej było w przypadku nośności granicznej. W belce B3 
(wzmocnionej bez sprężenia, z zakotwieniami) jej wartość była wyższa w porównaniu z belką wzmocnioną bez zakotwień (B2). We wszystkich sprężonych belkach zanotowano zbliżone wartości nośności granicznej - ok. $420 \mathrm{kNm}$.

Wykres na rys. 7 przedstawia krzywe zależności ugięcia od obciążenia dla wszystkich badanych belek. Widoczne odchylenie krzywych $M-\delta$ dla belek wzmocnionych od krzywej reprezentującej belkę referencyjną świadczy o wzroście sztywności na skutek wzmocnienia. Wzrost sztywności belek wzmocnionych przekłada się na redukcję ugięć. Przykładowo dla obciążenia równego $200 \mathrm{kNm}$ zmniejszenie ugięcia w belkach sprężonych wynosiło od 33\% dla belki B4 do $41 \%$ dla belki B6. Redukcja ugięcia w belkach B2 i B3 była mniejsza i wynosiła ok. 15\% w stosunku do belki referencyjnej.

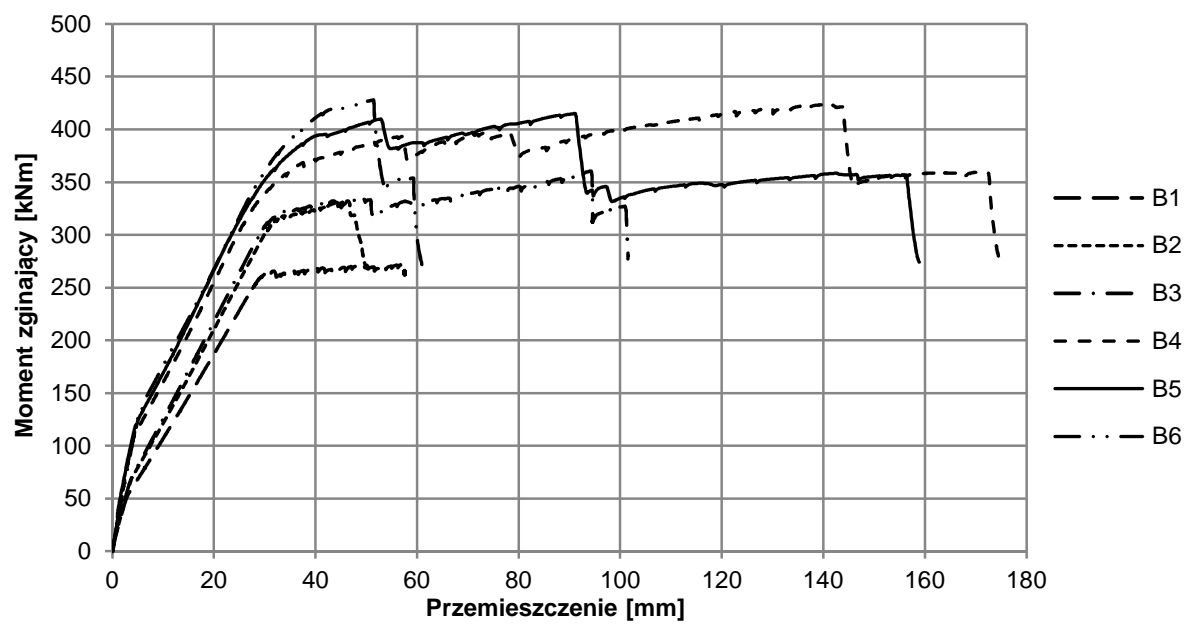

Rys. 7. Wykresy zależności ugięcia od obciążenia w środku rozpiętości belek

Fig. 7. Load - deflection plots in the middle of beams

Na rys. 8 przedstawiono porównanie zarysowania bocznej powierzchni badanych belek. W belce wzmocnionej taśmami biernymi B2 zaobserwowano większą liczbę rys o mniejszej szerokości rozwarcia w porównaniu z belką bez wzmocnienia. Podobny obraz zarysowania zarejestrowano w belce B3. W belkach B4-B6 na skutek sprężenia liczba rys uległa zmniejszeniu. Sumaryczna szerokość rozwarcia rys na jednej powierzchni belki była mniejsza w przypadku belek wzmocnionych taśmami. Przykładowo dla obciążenia momentem zginającym równym $200 \mathrm{kNm}$ nastąpiła redukcja z 4,25 mm dla belki B1 do $3,35 \mathrm{~mm}$ dla belek B2 i B3, czyli o ponad $20 \%$. W przypadku belek sprężonych ograniczenie to było jeszcze większe i wynosiło ponad $50 \%$. Ponadto podany poziom obciążenia w belce referencyjnej powodował powstawanie rys o szerokości rozwarcia $0,3 \mathrm{~mm}$, podczas gdy rysy w belkach wzmocnionych nie przekraczały $0,2 \mathrm{~mm}$. W belkach bez sprężenia liczba rys o tej szerokości rozwarcia była 
jeszcze znacząca, a w belkach sprężonych występowały pojedyncze takie rysy, bądź nie pojawiały się wcale.
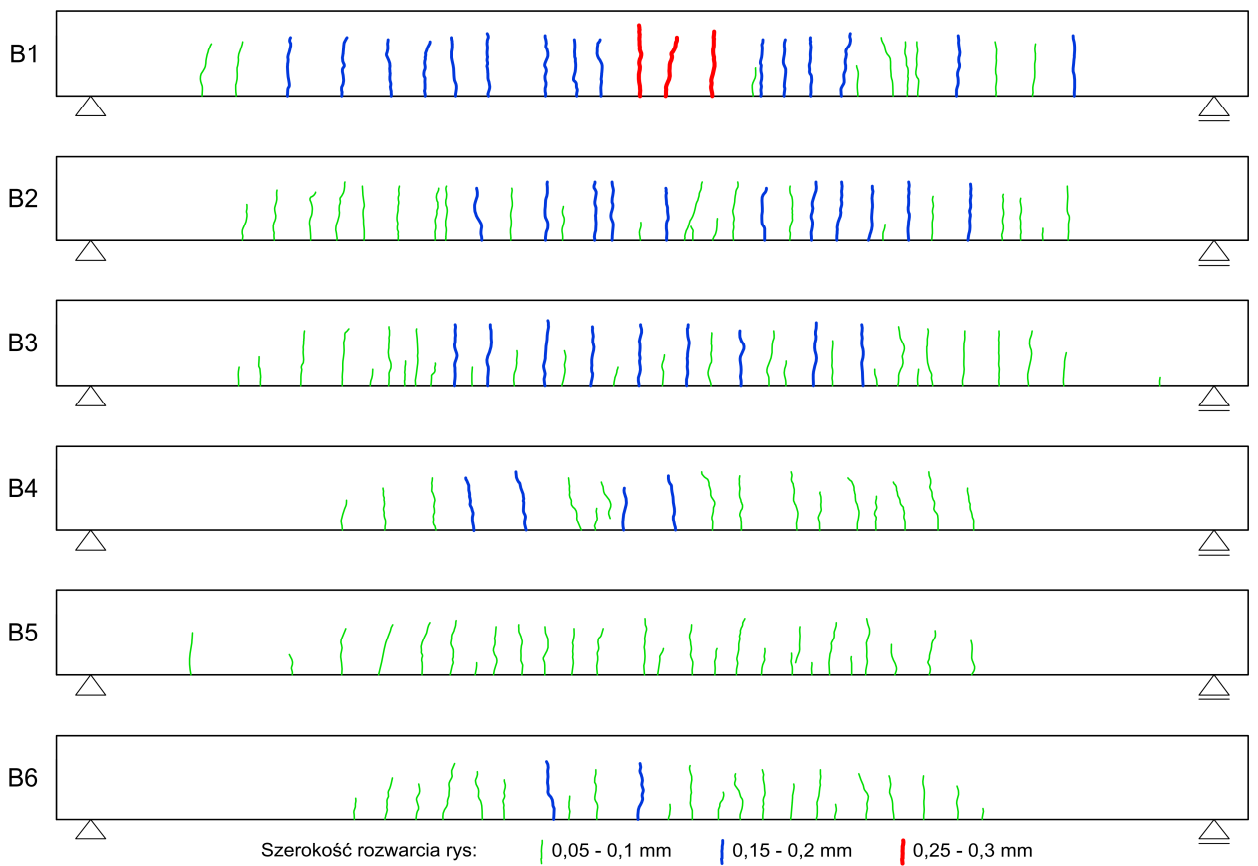

Rys. 8. Obraz zarysowania belek przy obciążeniu całkowitym 200 kNm

Fig. 8. Crack pattern under total load $200 \mathrm{kNm}$
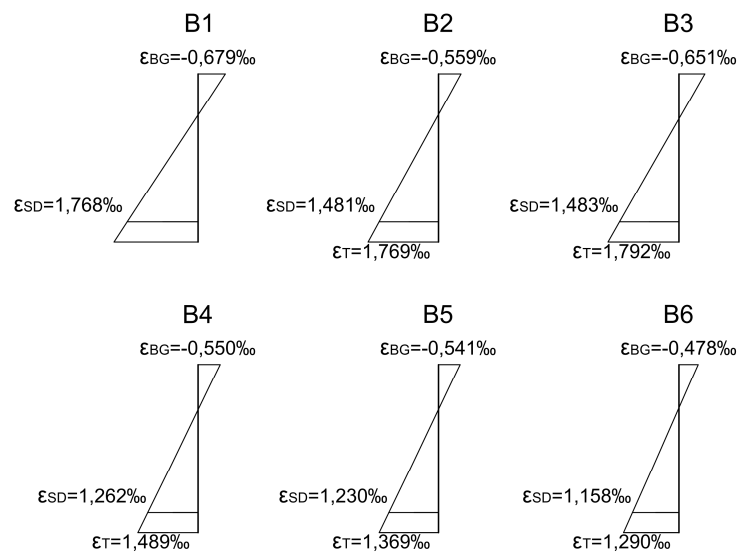

Rys. 9. Wykresy odkształceń w przekroju środkowym belek przy obciążeniu całkowitym $200 \mathrm{kNm}$

Fig. 9. Strain diagrams in the middle section of beams under total load $200 \mathrm{kNm}$ 
Wzmocnienie belek taśmami spowodowało redukcję odkształceń w betonie i stali zbrojeniowej. Wykresy charakteryzujące zmiany odkształceń w kolejnych belkach przy porównawczym obciążeniu $200 \mathrm{kNm}$ zestawiono na rys. 9. W przypadku belki z zerowym stopniem naprężenia B3 redukcja odkształceń w betonie na górnej powierzchni belek wynosiła 4\%, a w stali zbrojeniowej $16 \%$. W belach sprężonych (B4-B6) redukcja odkształceń w obu materiałach była większa i wynosiła od 19 do $30 \%$ w przypadku betonu i od 29 do $35 \%$ w przypadku stali zbrojeniowej. Wytężenie belek malało wraz ze wzrostem stopnia naprężenia taśm. Jest to widoczne również $\mathrm{w}$ zmianach odkształceń w taśmach CFRP. W belce wzmocnionej biernie zanotowano $18 \%$ redukcję odkształceń w betonie i $16 \%$ redukcję odkształceń w stali zbrojeniowej.

Rys. 10 przedstawia rozkłady odkształceń od obciążenia zewnętrznego $\left(\varepsilon_{1}\right)$ oraz rozkłady odkształceń całkowitych $\left(\varepsilon_{\mathrm{p}}+\varepsilon_{1}\right)$, wywołanych siłą naciągu i obciążeniem zewnętrznym, na długości taśm CFRP w belkach sprężonych przy obciążeniu $400 \mathrm{kNm}$. Odkształcenia pochodzące od obciążeń zewnętrznych malały wraz ze wzrostem stopnia naprężenia taśm. Jest to związane $\mathrm{z}$ większą sztywnością belek mocniej sprężonych. Natomiast odkształcenia sumaryczne były większe przy wyższych poziomach naprężenia, co przekładało się na wyższy stopień wykorzystania materiału kompozytowego w chwili zniszczenia.

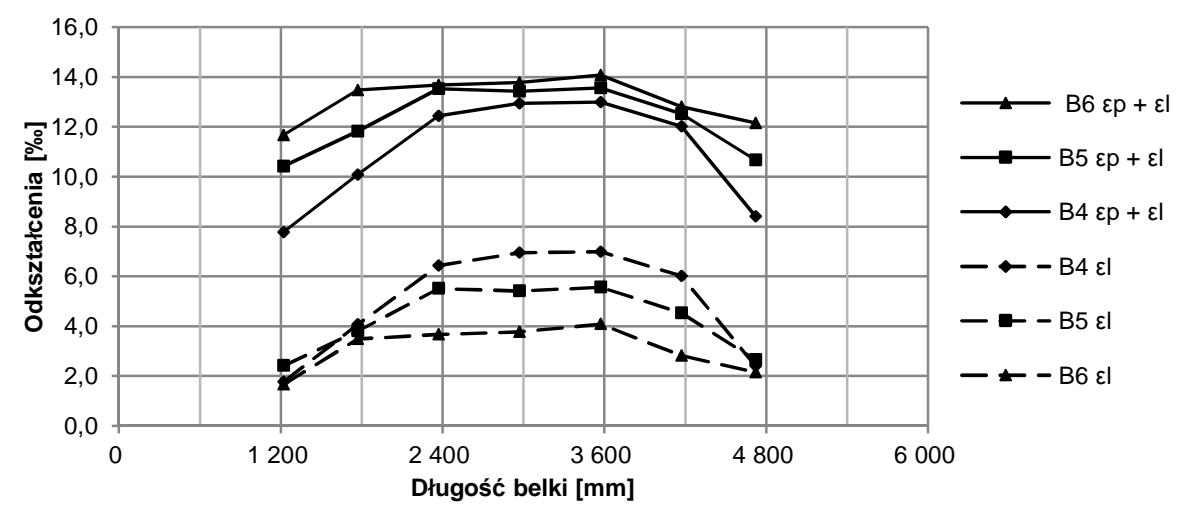

Rys. 10. Rozkłady odkształceń na długości taśm w belkach B4-B6

Fig. 10. Strains distributions along the strips in beams B4-B6

Rozkład odkształceń na długości taśm kompozytowych przy kolejnych poziomach obciążenia w belkach B2 i B3 przedstawiono na rys. 11. Odspojenie taśm w obu belkach następowało przy odkształceniach o wartości ok. 6\%o. Odspojenie taśm $\mathrm{w}$ belce $\mathrm{B} 2$ wiązało się $\mathrm{z}$ całkowitym zniszczeniem zbrojenia i utratą nośności. W przypadku belki B3 po odspojeniu taśma była jeszcze przez pewien czas utrzymywana $\mathrm{w}$ zakotwieniach, co pozwoliło na przeniesienie większych obciążeń (o $9 \%$ w porównaniu z belką B2). Utrata nośności nastąpiła na skutek wysunięcia taśm z zakotwień. Maksymalne odkształcenia przy zniszczeniu belki B3 wynosiły niespełna $8 \%$. 


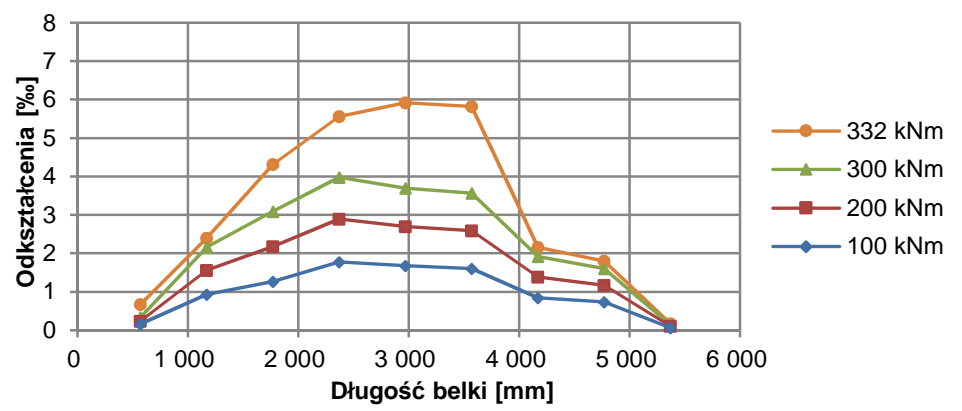

a)

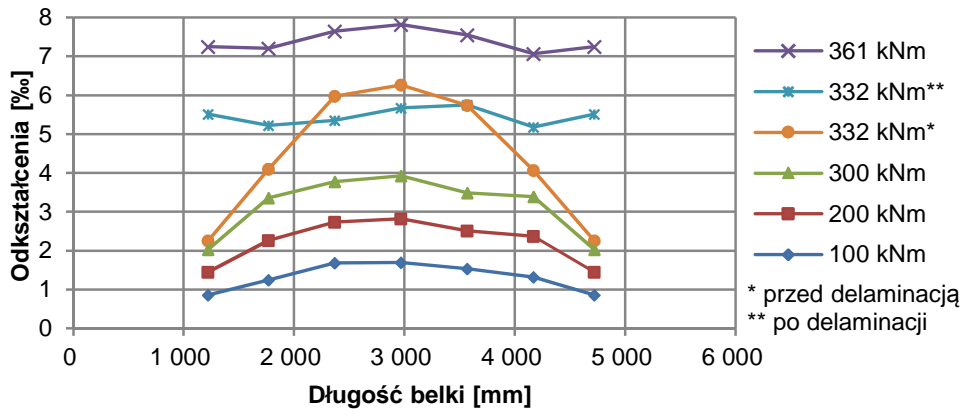

b)

Rys. 11. Rozkład odkształceń na długości taśm w belce a) B2 i b) B3

Fig. 11. Strain distribution along the strips in beam a) B2 and b) B3

Postać zniszczenia belek była uzależniona od sposobu wzmocnienia i poziomu siły sprężającej. Belka referencyjna uległa zniszczeniu poprzez nadmierne ugięcie wskutek uplastycznienia zbrojenia stalowego. Po uplastycznieniu prętów zbrojeniowych i ustabilizowaniu obciążenia przerwano badanie i odciążono belkę. Belka B2 uległa zniszczeniu poprzez odspojenie taśm, zapoczątkowane w strefie działania momentu zginającego i siły poprzecznej, postępujące w kierunku ich końców (tzw. intermediate crack debonding). Belka B3 została zniszczona na skutek wysunięcia uprzednio odspojonych (jak w przypadku belki B2) taśm $\mathrm{z}$ zakotwień stalowych. W belkach B4 i B5 wystąpiła podobna postać zniszczenia, jak w przypadku belki B3, przy czym w belce B4 nastąpiło całkowite zniszczenie obu taśm (rys. 12a). W belce B5 jedna taśma uległa zniszczeniu, a druga wysunięciu z zakotwień. Zniszczenie taśm nie było spowodowane wyczerpaniem ich wytrzymałości na rozciąganie. Następowało na skutek uwolnienia dużej energii po wysunięciu naprężonych taśm z zakotwień. Belka B6 uległa nagłemu zniszczeniu na skutek wysunięcia taśm z zakotwień, bez wystąpienia uprzedniego odspojenia taśm (rys. 12b). W tym przypadku nie zaobserwowano również poawaryjnej fazy pracy belki. Jest to spowodowane dużym poziomem wstępnych odkształceń wprowadzonych w taśmy na skutek naprężenia. 
a)
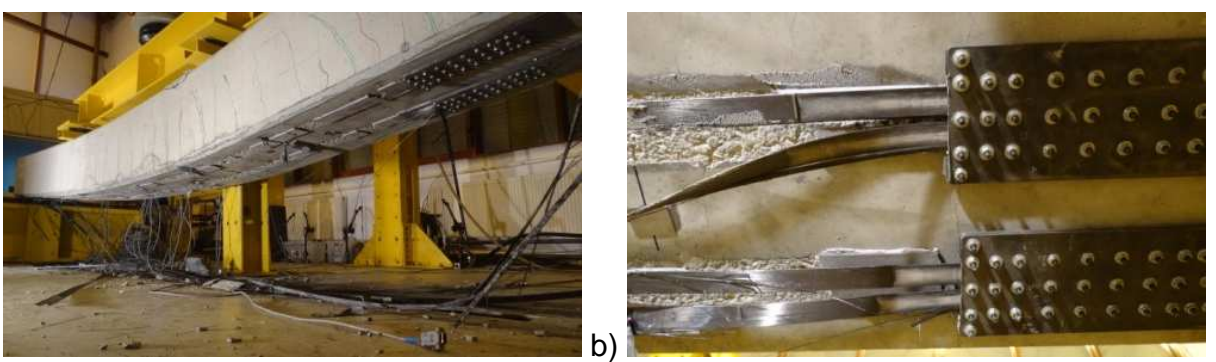

Rys. 12. Postać zniszczenia belki B4 (a) i taśmy wysunięte z zakotwień w belce B6 (b)

Fig. 12. Failure mode of beam B4 (a) and failure of anchorages in beam B6 (b)

\section{Porównanie wyników badań z obliczeniami}

Przed wykonaniem badań przeprowadzono obliczenia analityczne na podstawie własnej procedury obliczeniowej sporządzonej w oparciu o wytyczne zawarte w literaturze $[3,12,13]$. Dla wszystkich belek wyznaczono wartości momentów rysujących, momentów uplastycznienia stali zbrojeniowej oraz nośności granicznych. Wyznaczono także obliczeniowe krzywe zależności ugięcia od obciążenia wg [14].

W tabl. 3 zestawiono wyniki obliczeń $\left(\mathrm{M}_{\mathrm{cr}, \mathrm{obl}}, \mathrm{M}_{\mathrm{y}, \mathrm{obl}}, \mathrm{M}_{\mathrm{u}, \mathrm{obl}}\right) \mathrm{z}$ wartościami otrzymanymi w badaniach doświadczalnych ( $\mathrm{M}_{\mathrm{cr} \text {,dośw }}, \mathrm{M}_{\mathrm{y}, \text { dośw }}, \mathrm{M}_{\mathrm{u}, \text { dośw }}$ ). Wartości obliczone nie odbiegały znacząco od wartości otrzymanych z badań. Maksymalna różnica nie przekraczała 15\%, a w przypadku nośności granicznej - $6 \%$.

Tabela 3. Porównanie wyników badań z obliczeniami

Table 3. Comparison of test and calculation results

\begin{tabular}{|c|c|c|c|c|c|c|}
\hline \multirow{2}{*}{ Belka } & \multicolumn{2}{|c|}{ Moment rysujący } & \multicolumn{2}{c|}{ Moment uplastycznienia stali } & \multicolumn{2}{c|}{ Nośność graniczna } \\
\cline { 2 - 7 } & $\mathrm{M}_{\mathrm{cr}, \mathrm{obl}}$ & $\mathrm{M}_{\mathrm{cr}, \mathrm{dos} w}$ & $\mathrm{M}_{\mathrm{cr}, \mathrm{obl}}$ & $\mathrm{M}_{\mathrm{y}, \text { dośs }}$ & $\mathrm{M}_{\mathrm{u}, \mathrm{obl}}$ & $\mathrm{M}_{\mathrm{u}, \mathrm{dośw}}$ \\
\cline { 2 - 7 } & {$[\mathrm{kNm}]$} & {$[\mathrm{kNm}]$} & {$[\mathrm{kNm}]$} & {$[\mathrm{kNm}]$} & {$[\mathrm{kNm}]$} & {$[\mathrm{kNm}]$} \\
\hline B1 & 63,5 & 55 & 249 & 266 & 262 & 272 \\
\hline B2 & 64,3 & 70 & 281 & 318 & 319 & 332 \\
\hline B3 & 64,3 & 72 & 281 & 321 & 338 & 361 \\
\hline B4 & 110 & 111 & 340 & 371 & 425 & 424 \\
\hline B5 & 126 & 120 & 360 & 394 & 429 & 415 \\
\hline B6 & 141 & 136 & 380 & 419 & 433 & 428 \\
\hline
\end{tabular}

Na rys. 13 zamieszczono porównanie wykresu zależności ugięcia od obciążenia uzyskanego w obliczeniach i badaniach na przykładzie belki B4. Zastosowany algorytm wyznaczania krzywej ugięcia prawidłowo odzwierciedla charakter pracy wzmocnionej belki. 


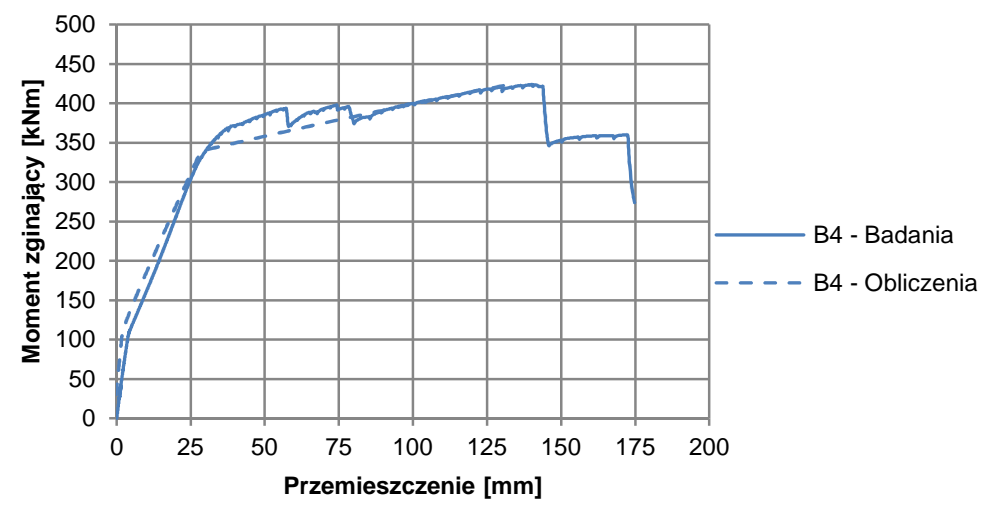

Rys. 13. Porównanie wykresów zależności ugięcia od obciążenia uzyskanych w obliczeniach i badaniach dla belki B4

Fig. 13. Comparison of load-displacement plots obtained in calculations and test for beam B4

\section{Analiza wyników}

Do szczegółowej oceny zachowania belek pod obciążeniem statycznym wykorzystano kilka parametrów charakteryzujących ich pracę. W tabl. 4 zamieszczono:

- stosunek nośności granicznej do momentu, przy którym doszło do odspojenia taśm: $\mathrm{M}_{\mathrm{u}} / \mathrm{M}_{\mathrm{d}}$

- współczynnik przemieszczeń plastycznych po odspojeniu taśm: $\mu_{\Delta}=\Delta_{\mathrm{u}} / \Delta_{\mathrm{d}}$ (stosunek ugięcia belki przy zniszczeniu do ugięcia przy odspojeniu taśm),

- efektywność wzmocnienia w zakresie sprężystym: $\eta_{\mathrm{e}}=\left(\mathrm{M}_{\mathrm{yi}}-\mathrm{M}_{\mathrm{y} 1}\right) / \mathrm{M}_{\mathrm{y} 1}$ (stosunek różnicy momentu uplastycznienia stali w belce wzmocnionej i referencyjnej do momentu uplastycznienia stali w belce referencyjnej),

- efektywność wzmocnienia w zakresie nośności granicznej: $\eta=\left(\mathrm{M}_{\mathrm{ui}}-\mathrm{M}_{\mathrm{u} 1}\right) / \mathrm{M}_{\mathrm{u} 1}$ (stosunek różnicy nośności granicznej w belce wzmocnionej i referencyjnej do nośności granicznej belki referencyjnej),

Tabela 4. Parametry opisujące zachowanie belek

Table 4. Parameters describing behaviour of the beams

\begin{tabular}{|c|c|c|c|c|c|}
\hline Belka & $\mathbf{M}_{\mathbf{u}} / \mathbf{M}_{\mathbf{d}}$ & $\boldsymbol{\mu}_{\boldsymbol{\Delta}}$ & $\boldsymbol{\eta}_{\mathbf{e}}$ & $\boldsymbol{\eta}$ & $\boldsymbol{\eta}_{\boldsymbol{\sigma}}$ \\
\hline B2 & 1,00 & 1,00 & $20 \%$ & $22 \%$ & $30 \%$ \\
\hline B3 & 1,09 & 2,19 & $21 \%$ & $33 \%$ & $39 \%$ \\
\hline B4 & 1,08 & 2,48 & $39 \%$ & $56 \%$ & $79 \%$ \\
\hline B5 & 1,01 & 1,73 & $48 \%$ & $53 \%$ & $82 \%$ \\
\hline B6 & 1,00 & 1,00 & $58 \%$ & $57 \%$ & $84 \%$ \\
\hline
\end{tabular}


- stopień wykorzystania taśm CFRP: $\eta_{\sigma}=\sigma_{\max } / f_{f u}$ (stosunek maksymalnych naprężeń uzyskanych w taśmie do wytrzymałości kompozytu CFRP na rozciąganie).

Wartość stosunku nośności granicznej do momentu, przy którym dochodzi do odspojenia taśm CFRP charakteryzuje zapas bezpieczeństwa powstały na skutek występowania zakotwień oraz poawaryjnej fazy pracy belki po odspojeniu taśm. W belce B3 po odspojeniu taśm zakotwienia umożliwiły dalszy przyrost obciążeń do wartości 109\% obciążenia, przy którym nastąpiło odspojenie. Podobna sytuacja miała miejsce w przypadku belki B4 z 30\% poziomem naprężenia taśm. W belkach mocniej sprężonych przyrost nośności był już znikomy (dla belki B5 wynosił 1\%) lub nie występował wcale, jak w przypadku belki B6, gdzie odspojenie taśm nastąpiło w tym samym momencie, co całkowite zniszczenie wzmocnienia. W przypadku belki B2, gdzie nie zastosowano zakotwień nie występuje poawaryjna faza pracy i parametr ten również wynosi 1,00.

Kolejny analizowany parametr - stosunek ugięcia przy zniszczeniu do ugięcia przy odspojeniu taśm charakteryzuje plastyczność zachowania belki w fazie poawaryjnej, co przekłada się na szybkość zniszczenia wzmocnienia. Im wyższa wartość tego współczynnika, tym zniszczenie jest bardziej sygnalizowane, jak w przypadku belek B3 czy B4. Natomiast w belkach, gdzie występowało nagłe zniszczenie (B6 i B2) współczynnik wynosi 1,00. Na podstawie powyższych wyników można stwierdzić, że plastyczność belek sprężonych spada wraz ze wzrostem poziomu naprężenia taśm.

W przypadku belek sprężonych widać wyraźny wzrost efektywności wzmocnienia w zakresie sprężystym wraz ze wzrostem poziomu naprężenia. Efektywność ta dla belki wzmocnionej biernie B2 wynosiła 20\%, a obecność zakotwień w belce B3 nie wpłynęła znacząco na jej wartość. Nie zanotowano natomiast wpływu poziomu naprężenia na efektywność wzmocnienia w zakresie nośności granicznej. We wszystkich sprężonych belkach wartości efektywności wzmocnienia były zbliżone - na poziomie ok. 55\%. Na skutek zastosowania zakotwień w belce B3 nastąpił wzrost nośności granicznej w porównaniu z belką B2 o $9 \%$.

Stopień wykorzystania materiału kompozytowego w przypadku belki wzmocnionej biernie bez zakotwień (B2) był niewielki i wynosił 30\%. Taki wynik znajduje potwierdzenie w literaturze $[2,3,4]$. Po zastosowaniu zakotwień $\mathrm{z}$ połączeniem nitowanym w belce B3 wykorzystanie kompozytu wzrosło jedynie do $39 \%$. Nie jest to zadowalający wynik z punktu widzenia efektywności systemu. Wartość ta jest zaskakująca w świetle wyników badań nośności pojedynczych zakotwień, gdzie uzyskiwano siły niszczące zakotwienie o wartości powyżej $70 \%$ wytrzymałości kompozytu na rozciąganie $[9,10]$. Z pewnością ten wynik można byłoby poprawić stosując zakotwienia śrubowe, które zdały egzamin przy kotwieniu taśm $w$ belkach sprężonych, testowanych $\mathrm{w}$ drugim etapie badań. W przypadku tych belek wykorzystanie materiału kompozytowego wynosiło ok. $80 \%$ i nieznacznie rosło wraz ze wzrostem poziomu naprężenia taśm. 


\section{Podsumowanie}

Wzmocnienie belek żelbetowych za pomocą taśm wstępnie naprężanych spowodowało bardzo duży wzrost nośności granicznej (o ponad 50\%). Zmiana poziomu naprężenia taśm nie wpłynęła na poziom nośności granicznej belek. Miała ona natomiast istotny wpływ na stany graniczne użytkowalności belek. Wraz ze wzrostem poziomu naprężenia taśm następował wzrost wartości momentów rysujących (ponad dwukrotny) i momentów uplastycznienia zbrojenia stalowego (do 58\%) oraz ograniczenie ugięcia i zarysowania belek. Wyniki przeprowadzonych badań znajdują potwierdzenie w literaturze [4, 5]. Wzrost poziomu naprężenia taśm prowadzi także do zmniejszenia plastyczności belek i zwiększania szybkości z jaką dochodzi do zniszczenia. Belka z najwyższym poziomem naprężenia taśm charakteryzowała się nagłym zniszczeniem, podczas gdy $\mathrm{w}$ belkach $\mathrm{z}$ niższymi poziomami naprężenia zniszczenie przebiegało w sposób stopniowy i sygnalizowany.

Wzmocnienie belek taśmami przyklejonymi bez wstępnego naciągu spowodowało niewielki wzrost ich sztywności oraz znaczący wzrost nośności granicznej o $22 \%$ dla belki B2 i 33\% dla belki B3. Zastosowanie zakotwień mechanicznych na końcach taśm wpłynęło na przedłużenie pracy belki o dodatkową poawaryjną fazę oraz zwiększenie nośności granicznej o 9\% w stosunku do belki wzmocnionej biernie bez zakotwień. Dostępne w literaturze wytyczne i procedury obliczania wzmocnień taśmami CFRP $[2,12,13,14]$ pozwalają w dokładny sposób oszacować nośność wzmocnionych belek.

Weryfikacja działania nowego systemu wzmacniania NPS II przebiegła pomyślnie zarówno pod kątem efektów wzmocnienia jak i ergonomii jego stosowania. System po sprawdzeniu na belkach doświadczalnych w laboratorium jest w pełni przygotowany do zastosowania $\mathrm{w}$ warunkach in situ.

\section{Literatura}

[1] Zoghi M.: The International Handbook of FRP Composites in Civil Engineering, Taylor \& Francis Group, Boca Raton, 2014.

[2] Meier U., Kotynia R.: Wzmacnianie konstrukcji żelbetowych naprężonymi materiałami kompozytowymi FRP, Inżynieria i Budownictwo, nr 11/2006, s. 596-599.

[3] Łagoda M.: Wzmacnianie mostów przez doklejanie elementów. Monografia 322. Seria: Inżynieria Lądowa, Politechnika Krakowska, Kraków 2005.

[4] Kotynia R.: Wpływ ukształtowania zewnętrznego zbrojenia kompozytowego CFRP na efektywność wzmocnienia belek żelbetowych. Inżynieria i Budownictwo, nr 1/2005, s. 27-31.

[5] Kałuża M., Ajdukiewicz A.: Comparison of Behaviour of Concrete Beams with Passive and Active Strengthening by means of CFRP Strips, Architecture Civil Engineering Environment - ACEE, No. 2/2008, s. 51-64.

[6] Kotynia R.: Przyczepnościowe metody wzmacniania konstrukcji żelbetowych przy użyciu naprężonych kompozytów polimerowych, Przegląd Budowlany, nr 7-8/2015, s. 49-56. 
[7] Siwowski T., Michałowski J., Błażewicz S.: Nowy system sprężania taśm kompozytowych CFRP do wzmacniania konstrukcji żelbetowych, Inżynieria i Budownictwo, nr 3/2010, s. 152-156.

[8] Tines Composites SA: Karta informacyjna produktu. NEOXEPLATE - Taśmy kompozytowe CFRP do wzmacniania konstrukcji, 2015.

[9] Paśko P., Piątek B., Siwowski T.: Badania zakotwień w systemie wzmacniania konstrukcji sprężonymi taśmami CFRP., Budownictwo i Architektura, nr 13(3)/2014, s.143-150.

[10] Piątek B., Siwowski T.: Badania statyczne i zmęczeniowe zakotwień sprężonych taśm CFRP do wzmacniania konstrukcji budowlanych, Inżynieria i Budownictwo, nr 1/2016, s. 24-28.

[11] Tines Composites SA: Karta informacyjna produktu. NEOPOXE 30 - Klej epoksydowy do mocowania elementów wzmocnień konstrukcji, 2015.

[12] FIB Task Group 9.3: Externally Bonded FRP Reinforcement for RC Structures, Technical Report, Fib Bulletin 14, CEB-FIP, Lausanne, Switzerland, 2001.

[13] CNR-DT 200/2004 - Guide for the Design and Construction of Externally Bonded FRP Systems for Strengthening Existing Structure. Rome, Italy, 2004.

[14] Pellegrino, C., Modena, C.: Flexural Strengthening of Real-Scale RC and PRC Beams with End-Anchored Pretensioned FRP Laminates, ACI Structural Journal, No. 3/2009, s. 319-328.

\section{STRENGTHENING EFFICIENCY OF RC BEAMS POST-TENSIONED WITH CFRP STRIPS}

\section{S u m m a r y}

CFRP strips are nowadays widely used in civil engineering. Thanks to high mechanical parameters, they are ideal for strengthening reinforced concrete structures. There are two ways of strengthening: passive, where CFRP strips are only glued to the concrete surface and active, where CFRP strips are glued after tensioning and they are additionally anchored to the structure. The paper presents research on reinforced concrete beams flexural strengthened by active and passive CFRP. The main goal of the research was to analyze influence of prestressing level on the strengthening efficiency of the beams and the influence of using mechanical anchorages. Additional aim was to examine the new structural strengthening system NPS II in practice. The beams were strengthened in tension zones and subjected to static four-point bending. Strengthened beams have shown higher load-bearing capacity in comparison with reference beam $(20 \div 30 \%$ for beams strengthened by passive strips and about $55 \%$ for beams strengthened by active strips). The increase of prestressing level resulted in increasing of beams stiffness but it has not influence on the load-bearing capacity. Moreover, beams with higher prestressing level have shown lower ductility. The use of anchorages in beams with passive strips allows to continuation of working RC beams after strips debonding. The research has confirmed the usefulness of the new system to strengthening reinforced concrete structures. The system is now fully prepared for the implementation in situ.

Keywords: anchorages, bending, carbon fibre, prestressing, strengthening system 